This is an Accepted Manuscript of a book chapter published by Routledge in Development and Poverty Reduction: A Global Comparative Perspective on 28 October 2019, available online: https://doi.org/10.4324/9780429292125. Accepted version downloaded from SOAS Research Online: http://eprints.soas.ac.uk/32039

\title{
An Overview of Recent Trends in Official Development Assistance:
} Contradictory New Directions in the Relationship between DAC Donors and China

\author{
Mark McQuinn
}

\section{Author's profile}

Dr Mark McQuinn is a lecturer and researcher in Development Studies at the School of Oriental and African Studies, University of London, who worked in the NGO sector for a number of years. He has worked on various political economy issues in Tanzania, Ghana, Sierra Leone, the Sudan and the Gambia. He is researching two issues: the use of financial investments by trade unions as a vehicle for capacity building in Africa and, secondly, African trade unions strategies in defending the interests of labor. Dr McQuinn has undertaken a number of consultancies, including the co-production of an analysis of possibilities for urban development and jobs creation in secondary cities in Tanzania. He is the author the book, Civil Society as a Conflictual Sphere in Tanzania: The Role of Trade Unions, and co-author of a book outlining ways for grassroots NGOs to undertake self-evaluation and monitoring.

\section{Introduction}

The provision of Official Development Assistance (ODA) is at a critical juncture for a number of reasons. First, the rise of right-wing populism in a number of donor countries has led to vociferous arguments for reductions in foreign aid. It has also precipitated calls for donor aid policies to be driven overtly by economic self-interest and a securitization agenda. Second, an anti-aid narrative is being driven by rightwing sections of the media in donor countries, such as the UK. This focuses on the perceived prioritization of the welfare of foreigners above domestic citizens, illconceived aid programs, corrupt practices and abusive behavior by staff involved in providing assistance. Third, there has been a shift in the overarching perspective of traditional aid providers. ${ }^{1}$ At the Busan High-Level Forum (HLF4) meeting of the Organization for Economic Cooperation and Development (OECD)-Development Assistance Committee (DAC) ${ }^{2}$ donors in 2011, a focus on 'development effectiveness' emerged (Mawdsley, Savage and Kim, 2014). This diverges from the paradigm outlined and developed at the previous three high level fora (HLF1-3), held 
in Rome (2003), Paris (2005) and Accra (2008). The HLF1-3 paradigm is based on using aid primarily to directly target poverty reduction. The shift by DAC donors to a broader objective of providing aid for development effectiveness is influenced by two main factors. First, a desire to increase the involvement of a wider group of actors in aid provision, particularly the private sector. Second, a need to increase collaboration with non-traditional donors, in order to make achieving the Sustainable Development Goals (SDGs) by 2030 a realistic proposition. However, an important new aim of US Official Development Assistance (ODA) is to provide a counterweight to the influence of China in aid recipient countries. Many 'U.S. foreign affairs officials have pointed to countering China’s influence as a key objective of their agency’s programs' (Igoe, 2018a). There are, thus, contradictory directions developing, as the most powerful member of the DAC, the US, takes a more overtly oppositional stance to Chinese aid than other donors in the group. Irrespective of the position taken towards its aid provision by DAC members, China is of rising importance in shaping the ideology, policies and practices of aid. Ideologically, China is less influenced by a market-driven aid model than the Western multilateral and bilateral donors. Its aid policies and practices also diverge notably from those of traditional aid providers. While China is diversifying its aid provision, the development of infrastructure remains a key element of its assistance. China’s Ambassador to Nigeria, Zhou Pingjian, for example, stated in March 2018 that 'China's financing support to Africa is mainly invested in infrastructure construction...We are committed to intensive development. The large infrastructure projects are planned and moved forward along with promoting Africa's industrial development' (Pingjian, 2018).

This chapter provides an overview of the interrelated issues affecting ODA and situates a discussion of future trajectories for aid relations between traditional donors and China within these complex strands. It argues that, while significant shifts in the form of aid are inevitable, the direction of these changes is far from clear. Aspects of the Chinese model, based on blending aid with different forms of commercial investment, are likely to become more widely adopted by traditional donors. However, whether they will use a blending model in collaboration with Chinese development assistance to pursue large infrastructure projects, as part of a development effectiveness agenda, is more contentious. It is unlikely that traditional donors will switch their aid modalities significantly to come more into line with the Chinese model. The thinking behind the provision of aid by China for infrastructure projects, such as roads and 
energy, draws on the structuralist model that was prevalent in the 1960s. This approach centers on providing support for state-led development. Such a perspective is problematic for traditional donors, given their recent shift to an overt emphasis on the primacy of the private sector in providing aid. Any attempt to move aid towards a model based on a leading role for the state at the recipient end in coordinating major infrastructure development is likely to be opposed by budget holders and policy makers at multilateral aid providers (notably the World Bank and the International Monetary Fund) and at bilateral organizations, such as USAID and the UK's Department for International Development (DFID).

Two main implications for future studies emerge from this overview. First, more research is required on how realistic synergies are between traditional donors and China, given their divergent ideological, economic and political perspectives. Second, more evidence-based studies on the outcomes of Chinese aid are needed. Much analysis of Chinese development assistance remains based on broad generalizations concerning its benefits and shortcomings. There is a need for detailed analyses of the concrete outcomes for the intended beneficiaries of Chinese aid programs and projects.

The chapter is divided into six main sections. First, as ODA is under concerted attack, arguments in its favor are briefly revisited. Second, the major elements of the DAC's HLF aid paradigm are outlined, as they provide the framework for traditional ODA, which is facing intense pressure to change. Then three major critiques of the DAC model are discussed: literature focusing on the gap between the rhetoric and reality of aid provision; analyses advocating politically rooted solutions to aid failure; and the neoliberal critique, arguing that ODA should be halted and replaced by a market-led development trajectory. The next section discusses the implications of current attacks on aid by right-wing populists and sections of the media, linked to a move towards a securitization aid agenda on the part of important DAC donors. The literature on the growing significance of China as an aid provider, and its relationship with traditional donors, are assessed. The empirical focus of the chapter is predominantly on Africa. Finally, the central lines of argument in the different sections are brought together in the conclusions section.

\section{The Case for Aid in the Face of the Current Critical Onslaught}

Traditional aid provision by Western donors has its defenders, despite its increasing censure by neoliberals, right-wing populist political parties in donor 
countries and sections of the media. Analysts make a case for the continuing provision of aid, based on two main grounds. ${ }^{3}$ These formative reasons for giving ODA are worth revisiting, given the intensity of the criticisms facing aid at present.

First, giving aid has been justified on moral grounds. Following Singer's (1972) influential outline of the moral case for providing foreign aid to those in need, given the extent of poverty and deprivation that exists globally, a number of analysts have taken a similar stance. Riddell (2008: 413, 2011), for example, argues that there is a 'compelling case for governments to provide aid' on the grounds of moral duty, given the vast inequalities of wealth between rich and poor nations. Moreover, Hulme (2016) makes the point that aid is provided partly because some developed countries recognize their role in shaping the economic and political structures that have caused poverty in other nations (largely through colonialism and the slave trade).

Second, a case has been made for aid on the basis of its effectiveness in improving the lives of intended beneficiaries in the social and economic spheres. Sachs $(2014,2015,2017)$ points to a number of successful aid programs and projects over the years in the area of public health, including increased control of the incidence of malaria and tuberculosis in recipient countries. Sachs reiterated in 2015, his 'big push' argument, first outlined ten years previously: if external donors increase aid in the form of finance, as well as skills and technology transfer, the 'end of poverty' can be achieved. The developed world has the financial, technical and institutional capacities to make transformative change possible through aid: commitment is the main issue. More cautious analyses argue that aid is effective in certain contexts, to the extent that in its absence growth would be lower (McGillivray et al, 2011). The context in which aid works well, however, remains hard to determine (Edwards, 2014). Nevertheless, Arndt, Jones and Tarp (2016: 446) make the important summary point that 'the large majority of up-to-date empirical studies in the economics literature have found positive impacts' of aid at a macroeconomic level.

Thus, for a number of analysts, a moral imperative for the developed world to give aid remains and its provision has led to improvements in the social and economic welfare of recipients, which can be demonstrated empirically. These two factors combine uneasily and unevenly in influencing the policies and practices of traditional donors, which provide ODA under the auspices of the Development Assistance Committee (DAC) at the Organisation for Economic Cooperation and Development 
(OECD). The following section traces the development of the DAC model and highlights significant problems which its members find difficult to resolve.

\section{The Development of the DAC Aid Model}

Influenced by criticisms of donor behavior in Tanzania during the 1990s (Adams, 2005, Helleiner et al, 1995), DAC members have considerably revised their approach to ODA provision since 2000, at least rhetorically. Major policy documents, resulting from high-level DAC meetings, outline principles to frame the way aid should be given (OECD, 2003, 2005, 2008, 2011). DAC donors emphasize the need for aid to be provided within a wider context of policy coherence for development (PCD). This entails ensuring that 'the interactions among various policies in the economic, social, environmental, legal and political domains support countries on their pathway towards inclusive sustainable growth' (OECD, 2015: 2). PCD further necessitates putting in place institutional mechanisms, processes, and tools to produce effective, efficient, sustainable and coherent policies in all sectors (ibid). A major issue concerning the PCD approach is how to incentivize donors to turn their rhetoric into reality. Among EU donors, for example, there is scepticism about the plausibility of providing aid within a PCD context. In the sphere of trade, 'PCD-related measures in favour of developing countries look marginal in an overall EU strategy prioritising its economic and security interests' (Latek, 2015: 1).

The codification of aid principles has been developed at four DAC High-Level Fora (HLF) on Aid Effectiveness. ${ }^{4}$ The overarching aims of the HLF fora have been to learn the lessons of failures during the 1990s, in order to deliver aid more effectively, reduce transaction costs and increase the capacity of institutions in recipient countries to absorb and spend ODA. HLF1 in 2003 produced the Rome Declaration, outlining the need for donors to simplify and harmonize 'operational policies, procedures and practices' in order to avoid duplication (OECD, 2003). Two years later, HLF2 led to the publication of the Paris Declaration (OECD, 2005). As well as reemphasizing the importance of harmonization, the Paris Declaration outlined four other fundamental aid principles for donors: mutual accountability, the need for alignment with the wider development objectives of recipients, ownership of aid policies on the part of the intended beneficiaries and managing for achievable results. HLF3 in 2008 led to the Accra Agenda for Action (AAA), which emphasized the need to ensure that aid outcomes have a 'real and measurable impact on 
development' (OECD, 2008). The AAA also recognized for the first time Civil Society Organizations (CSOs) as 'development actors in their own right' (Oxfam, 2012: 3). At HLF4 in 2011 in Busan, two issues of importance to the analysis in this chapter were raised: it was stated that there was a need for the greater participation in aid provision of both non-traditional donors from the south and the private sector. It was acknowledged in the Busan Partnership for Effective Development Cooperation (BPEDC) that the 'Paris Declaration did not address the complexity of these new actors' and that 'South-South co-operation continues to evolve, providing additional diversity of resources for development' (OECD, 2011: 4). Furthermore, there was a pledge to 'enable the participation of the private sector in the design and implementation of development policies and strategies' (OECD, 2011: 10).

The BPEDC concludes by asserting that DAC donors will 'hold each other accountable for making progress against the commitments and actions agreed in Busan, alongside those set out in the Paris Declaration on Aid Effectiveness and Accra Agenda for Action' (OECD, 2011: 12). To this end, a Global Partnership for Effective Development Co-operation (GPEDC) has been created, which is responsible for implementing the commitments made at Busan. Finally, a Working Party on Aid Effectiveness (WP-EFF) has been established - consisting of representatives of the DAC and other stakeholders - to work on reaching an agreement on how to put the GPEDC into practice.

Overall, the DAC aid model has evolved since the Rome Declaration (2003) to take account of the increasingly complex architecture of ODA. The need to engage with a growing range of actors involved in the contemporary 'many-to-many' (Ramalingam, 2013: 5) world of aid provision is foregrounded in the Busan Principles. However, the core aid principles outlined in the HLF fora focus overwhelmingly on technical ways of providing aid effectively and lack nuanced engagement with complex socio-political structures and processes in both recipient and donor countries. Criticisms of the model have proliferated in the second decade of the twenty-first century. Only one year after the publication of the Accra Agenda for Action in 2008, for example, Whitfield (2009: 4) argued that 'everyone knows that foreign aid is not working as intended, and that something must change'. While shifts in DAC aid provision have occurred since this statement, a growing range of literature has continued to highlight the inadequacies of the model. Two main lines of criticism are outlined in the following section. 


\section{The DAC Aid Model under Increasing Pressure to Change}

Critics of the DAC aid model can be broadly divided into two camps. First, there are reformists who support the continued provision of aid but highlight the need to address problems with the model, which they identify as emanating from the political domain. In short, 'the politics matter' (Glennie, 2014: 553). Second, a number of neoliberals argue that the existing aid model is fundamentally flawed and should be radically altered or abandoned. The key arguments of these two lines of criticism are discussed in turn.

\section{The Rhetoric-Reality Gap in the Provision of Aid}

Donors have consistently failed to implement important principles outlined in DAC documents. The gap between the rhetoric contained in the DAC publications and the reality of aid provision on the ground remains significant. Problems in relation to, first, harmonization and second, ownership are used to illustrate this failing. These two concepts have been selected, as they have been emphasized as key to the success of aid since the 1980s by the World Bank, the largest and most influential Western donor (World Bank, 1988).

The first HLF (OECD, 2003) in Rome focused on the need for donor harmonization, in order to lower transaction costs. The Rome Declaration (OECD, 2003: 10) argues that it is beneficial to 'simplify and harmonise [aid] requirements and reduce their associated costs, while improving fiduciary oversight and public accountability and enhancing the focus on concrete development results.' However, studies since the publication of the Declaration highlight the continuing failure of donors to harmonize effectively. For AFRODAD (2007) harmonization in Cameroon has been negatively affected by the reluctance of donors to stop interfering in aid processes, along with weak recipient strategies and institutions. Woods (2008: 1221) shows that traditional donors find 'coordination among themselves very challenging'. Winters (2012: 36), using Indonesia as a case study, finds that harmonization is hampered because of 'the strategic interests of the donors, the incentives faced by aid bureaucrats and the variation in interests within aid-recipient governments.' Leiderer (2015: 1441) demonstrates that there remain 'strong disincentives for effective coordination, even between like-minded aid providers' and this is unlikely to change until there is a shift in incentive structures, so that donors' rhetorical commitment to 
harmonization will be translated into behavioral change. Olivie (2016) points out that lack of donor harmonization is caused not just by political incentives but also by the weak institutional capacity of both donors and recipients. She highlights the disorganised nature of the institutional aid architecture in some EU states, which has hindered the provision of harmonised ODA to Morocco. This is exacerbated by the lack of readiness and will to coordinate aid effectively on the part of the administration in Rabat.

These studies reveal that DAC aid provision continues to be based largely on individual donor self-interest, while recipients lack the institutional capacity and, in some cases, political will to engage effectively with harmonised ODA. Consequently, improved donor harmonization in providing aid has been fitful at best since its importance was highlighted in the Rome Declaration. The failure of traditional donors to harmonize their ODA effectively is exemplified by the point that 'the aid system supports some 15,000 donor missions in 54 recipients countries per year - and in some countries this amounts to over 20 official visits per week' (Ramalingam, 2013: 3). Winters (2012), points out that the continued provision of ODA by donors based on their individual concerns, weakens not only harmonization but also their claims that ownership of aid policies by recipient governments is important.

The significance accorded to ownership by DAC donors can be gauged from the fact that it is listed as the first of the key aid principles in the Paris Declaration, the Accra Agenda for Action and the Busan Partnership for Effective Development Cooperation. The focus of traditional donors on ownership precedes the Paris Declaration. In the early 1990s, Johnson and Wasty (1993) produced a piece of research for the World Bank, outlining detailed indicators of the concept and providing measurement criteria. This conceptualization of ownership influenced a later publication on the topic by the World Bank (2004). In addition, ownership became an important part of the practice of development in 1999 when it was made a defining concept of Poverty Reduction Strategy Papers (PRSPs). As Weeks et al. (2002: 72) point out, 'no single policy was more associated with transferring ownership to aid recipients than the Poverty Reduction Strategy Papers.' However, three years into the PRSP period, Cramer (2002) found that a theory of ownership was still lacking and Boughton and Mourmouras (2002) questioned whether it could be effectively operationalized. Despite the publication of these concerns, little detailed 
research by DAC donors ensued on how ownership should be theorised, operationalized and measured.

Ownership was defined by the DAC donors in 2005 in the Paris Declaration as a situation where aid recipients 'determine poverty reduction strategies autonomously, as well as focusing on institutional capacity building and addressing corruption’ (OECD, 2005). This broad and descriptive definition lacks analytical precision and makes accurate assessment of levels of ownership difficult. There is no detailed discussion in the Paris Declaration (or any of the other major DAC documents on aid provision) of the conceptualization of ownership and the measurement matrix provided by Johnson and Wasty (1993) and the World Bank (2004). Furthermore, the World Bank itself does not systematically use the measurement matrix. McQuinn (2012), examining the case of Tanzania, found that since the inception of PRSPs, the World Bank has not drawn on the classification scheme they published in 2004 to ascertain levels of ownership. The Bank, instead, measured the concept by employing broad rankings (from 1-5), assessing levels of participation as a proxy for ownership.

Analyses of ownership have expanded since its significance was foregrounded in the Paris Declaration, both at the theoretical and empirical levels (see, for example, Dornan, 2017, Fisher and Marquette, 2016, Rose and Wiebe, 2015, Vogus and Graff, 2015, Flint and Meyer zu Natrup, 2014, Buiter, 2010, Castel-Branco, 2008). Despite this body of work, an analytically rigorous and widely accepted characterization of the concept has remained elusive. In 2016, USAID still deemed it necessary to support research on defining ownership, resulting in the production of a working paper entitled Country Ownership In International Development: Towards a Working Definition (Watson-Grant et al, 2016).

The examples of harmonization and ownership illustrate the significant size of the gap between the DAC principles at a rhetorical level and the reality of aid provision. In many cases, harmonization and ownership failures derive from both structural power imbalances between donors and recipients and the entrenched political interests of groups and individuals within aid institutions. Notable aspects of these issues are discussed in the subsequent section.

\section{Aid Failure in the Context of Complex Political Realities}

Several recent analyses of ODA provided by traditional donors highlight contradictions between the current dictates of the aid system and the complex 
actuality of political relationships involving donors and recipients, which makes successful provision difficult.

First, aid failure has been linked to the over-concern of traditional donors with achieving value for money (VFM). The concept of VFM has recently 'become more prominent in the development agenda' (Jackson, 2012: 1) and can be categorized as a 're-emerging buzzword ... [with] ... a nice ring to it' (Jayasuriya, 2013: 1). ${ }^{5}$ For Yanguas (2018: 203), the 'VFM craze' illustrates the general point that traditional donors have created a transactional model of aid. Consequently, they are less concerned with transformational developmental outcomes than accounting for money expended on programs and projects. By concentrating on VFM, donors leave important and difficult political relationships and processes unaddressed, as they take time and are not easily amenable to quantitative measurement. The transactional nature of the system ensures that traditional aid providers concentrate on upward accountability to their funders, who prefer outcomes that can be enumerated and tabulated. This focus means that downward accountability to intended beneficiaries on the part of important aid providers, such as international NGOs, tends to be neglected (Lawrence, 2018, Banks, Hulme and Edwards, 2015).

Second, the preoccupation with VFM relates to the longer-standing concern of traditional donors with corruption. Anti-corruption programs have been a feature of traditional aid since the 1990s, as part of the wider donor-driven 'good governance' agenda (Dijkstra, 2017, Whaites et al, 2015, Sundaram and Chowdhury (eds), 2012, Grindle, 2007, Smith, 2007). While corruption in aid provision is far from a recent issue of concern, it rose to the top of the aid agenda in the latter part of 2017, driven by the critiques of neoliberals, right-wing populist politicians in donor countries and sections of the press, emphasizing the unprincipled nature of many programs. Corruption is clearly a verifiable problem in relation to aid provision. Manning (2012), for example, highlights the way aid has been used to strengthen the executive branch of recipient governments at the expense of countervailing forces, with negative consequences for local accountability. In a number of cases, a clique of ministers and other officials at the recipient end control aid flows and are distanced from rigorous oversight by parliaments, the media or civil society. Danish (2016) illustrates how this has happened in Afghanistan, where 'corruption consistently goes unpunished'. Kenny (2017), nevertheless, makes the point that the obsession of donors with reducing corruption, fueled by a defensive attitude to aid provision, has 
led to insufficient focus on the outcomes of programs and projects. Prevailing approaches to curbing corruption are costly and do not measure the phenomenon accurately. More attention should be paid to how the outcomes of aid programs and projects affect the intended beneficiaries. This is a significant point, which will be revisited in the section below on Chinese aid.

Third, a number of analysts focus on how the power of traditional donors entails a loss of policy space for recipients, through the imposition of conditionalities and overbearing policy advice. This inculcates policy incoherence in recipient governments and leads to a lack of long-term strategic visions, culminating in the demise of national development planning (Oya and Pons-Vignon, 2010). A study by Kentikelenis, Stubbs and King (2016) illustrates the salience of this perspective. Their research revealed that the IMF loan agreements between 1985 and 2014 contained 55,465 individual policy conditions across 131 countries. These statistics reveal the close control the IMF maintains over the policies of aid recipients and add weight to the argument of Winters (2012), outlined above, that ownership of aid policies by recipients remains more at the level of rhetoric than reality.

Fourth, a line of argument has been advanced that aid failure is inescapable within the system created by traditional providers, since it is based on compromises between donors and recipients that are unworkable in the long term. For Swedlund (2017), fads in aid delivery are attempts to overcome commitment problems that undermine policy agreements reached by providers and receivers. Incentives are required that realistically allow donors and recipients to fulfil their aid commitments. At present this is not the case and aid policies are based on negotiated settlements between providers and recipients, which break down, after an initial period of enthusiasm, due to constraints at both ends. Paul (2015) provides an illustration of this point in an examination of Performance-based Aid (PBA). She shows how donors have inadequately engaged with the fact that budgetary processes in recipient countries tend to be rigid. When donors release aid packages ex post, following what they have deemed to be an 'acceptable performance' by recipient governments in enacting 'necessary' policy reforms, a slow bureaucratic process towards final disbursement by various ministries occurs.

These critiques provide insights into the multiform political relationships involving aid donors and recipients, which militate against the success of programs and projects, within the existing system. They stop short of calling for a halt to aid 
and argue that meaningful reform is possible. Further down the critical line is a resurgent neoliberal perspective, which not only highlights serious aid failings but calls for ODA to be ended or changed beyond all recognition. This approach has been the subject of considerable analysis. However, since it has gained traction in the light of the rise of the populist right in a number of traditional donor countries and aid corruption scandals, core elements of the perspective are examined in the following section.

\section{The Influence of the Neoliberal Critique of Aid}

Drawing on the work of Bauer (1976), the neoliberal approach centers on the argument that development can be achieved, not through the provision of aid, but by greater integration of countries into a global free market economy. For Bauer (1981:

55) 'the concept of the Third World and the policy of official aid are inseparable. Without foreign aid there is no Third World.'

The neoliberal critique of aid increased in influence from the 1980s with support from prominent analysts, such as Friedman (1995). Neoliberals argue that aid is inefficient, since it typically entails market distortions in the form of subsidies and price controls. Furthermore, the provision of ODA creates a mentality of dependence among recipients and fosters corruption. It also, through ill-informed donor influence, leads to the misallocation of scarce resources, stifles innovation, and redirects the energies of entrepreneurs away from business towards lobbying to obtain aid contracts or attempting to join aid bureaucracies. In addition, aid precludes recipient governments from having to show 'good governance' to citizens and in particular taxpayers (Easterly, 2016).

Moyo (2010) contends that all aid should be halted within a five-year period, given its longstanding failure to stimulate development and reduce poverty. She argues that although Africans have received more than US\$1 trillion in development assistance, 'the recipients of this aid are worse off; much worse off. Aid has helped make the poor poorer, and growth slower. Yet aid remains a centrepiece of today's development policy and one of the biggest ideas of our time' (Moyo, 2010: xix).

This neoliberal perspective has influenced the recent shift by donors to marketdriven forms of aid provision. There is, therefore, a trend among major donors to shift 'official development assistance to their private development arms' (Anders, 2016). For example, in pursuing the SDGs, the World Bank (2015) states that 'financing 
from private sources, including capital markets, institutional investors and businesses, will become particularly important.' ${ }^{6}$ At a bilateral level, the Department for International Development (DfID) has foregrounded the importance of the private sector in the provision of UK aid. Its 2017 Aid Strategy document states that the organization will increase its use of capital 'to create jobs, catalyse private sector investment and build markets in challenging settings' (DFID, 2017: 10).

Overall, the neoliberal emphasis on the virtues of the free market, within which individual enterprise is key to economic success, resonates in the contemporary climate of fierce criticisms by right-wing populist politicians and media outlets of state-centered ODA provision. The nature of these critiques is summarized in the following section.

\section{Media and Right-wing Populist Attacks on Aid}

The rise of right-wing populism in donor countries, such as the UK and the US, has fostered a climate where foreign aid is routinely criticized in political speeches and media articles as wasteful and corrupt. In the UK, a number of right-wing publications have mounted concerted anti-aid campaigns over the last few years. The headlines below captures the essence of these critiques.

Daily Express - October 24, 2017

Foreign Aid: Let's STOP it NOW and spend BILLIONS on NHS and elderly - sign our petition

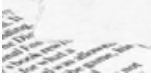

Source: https://www.express.co.uk/news/politics/870236/uk-foreign-aid-budgetbritish-give-money-india-africa-taxpayer-nhs-elderly

The Sun - February 20, 2018 


\section{AID FAIL FEAR Bloated British aid budget 'risks increase developing countries' dependency'}

Source: https://www.thesun.co.uk/news/5618203/bloated-foreign-aid-mayincrease-dependency-britain/

Daily Express - February 20, 2018

\section{FOREIGN AID FARCE: Government slammed over failure to monitor value for money of budget}

悹

Source: https://www.express.co.uk/news/politics/921122/Foreign-aid-budgetdamning-report-ICAI-Dfid-failure-monitoring-value-money

Daily Mail - March 17, 2018

\section{China takes millions in aid from the UK, then hands it to... Russia}

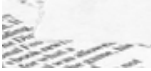

Source: http://www.dailymail.co.uk/news/article-5513567/China-takes-millionsaid-UK-hands-Russia.html

Such sustained censure influences the public's perception of aid. Revelations concerning the behavior of staff at well-known aid agencies, such as Oxfam, have exacerbated the media criticisms (Hirsch, 2018, Moise, 2018, Foulkes, 2018). Media coverage of misconduct by Oxfam staff has been cited as causing a fall in funds raised for UK Sport Relief 2018 by one third compared to the previous year (Siddique, 2018). Moreover, hostile media campaigns can have negative implications for government funding of ODA. Heinrich, Kobayashi and Bryant (2016) show that aid cuts can occur because politicians are aware that voters place a lower priority on ODA during periods of economic disquiet. In the majority of DAC donor countries, there is considerable economic uncertainty, which has precipitated calls by right-wing 
politicians for foreign aid to be reduced and reoriented towards securing national interests. The rising importance of such perspectives is discussed in the following section.

\section{Aid in support of Donors' National Interests}

The argument that aid is provided primarily to promote the national (and international) interests of donors is not new (see, for example, Hayter, 1971). However, in 2017 and 2018, forceful and direct arguments that aid should be redirected to serve their national interests have been outlined by important political figures from a number of DAC donors (Trump, 2018, for example). This adds another layer of complexity to debates concerning the future relationship between traditional donors and China in providing aid.

In 2018, senior politicians in the UK and the US have made strident calls for ODA to be aligned much more closely with their foreign policy and commercial interests. Boris Johnson, when British Foreign Secretary in 2017, stated in relation to aid that "the old jam jars are being smashed... [and] the cash will be more sensibly distributed with a view to supporting British foreign policy” (Barnett, 2017). His perspective is echoed by Penny Mordaunt, who shortly after becoming the Secretary of State for International Development in November 2017, outlined a vision for UK aid prioritizing “projects which deliver a much more explicit win for the UK's interests as well, because without that we won't be doing aid well” (Anders and Edwards, 2018).

These 'interests' center on security issues, as well as economic gain. For example, the UK National Security Council (NSC) now controls substantial funding streams for aid programs, such as the $2017 £ 1.7$ billion Conflict, Stability and Security Fund (CSSF). This is a cross-governmental fund, which aims to spend 30\% of ODA through departments other than DFID. Started in 2015, the CSSF is administered through the Foreign and Commonwealth Office (FCO). The UK government justifies this shift to a focus on aid for securitization by pointing to the vast amount human suffering globally caused by conflict and instability. This perspective is supported by the Independent Commission for Aid Impact (ICAI). In a 2018 review of the CSSF's aid programming expenditure, the ICAI found conflict to be 'both a major constraint on development and poverty reduction, and a source of 
threats to the UK and its interests.' (Independent Commission for Aid Impact, 2018: 1).

The CSSF is composed of blended ODA and non-ODA funds, such as spending on security issues or the military. This makes oversight problematic, since the ICAI is only mandated to evaluate ODA. Concern has been expressed by the then Chief Commissioner, who asks 'how can we ... say meaningful things about effectiveness of programing when actually there is quite a lot of blending going on?' (Anders, 2017). Where ODA provided by the CSSF is clearly delineated, its quality has been criticised. The 2018 ICAI evaluation of the CSSF's work led to the award of an amber-red assessment, signalling 'unsatisfactory achievement in most areas, with some positive elements ... improvements are required for UK aid to make a positive contribution (Independent Commission for Aid Impact, 2018). The same evaluation highlights the importance attached to VFM, which was outlined in section 3 above. One of the core recommendations of the evaluation is, "where the CSSF projects are intended to support diplomatic access and influence, the influencing objectives should be explicit and progress reported so that the value for money of the investment can be confirmed' (Independent Commission for Aid Impact, 2018: 1).

As well as the UK, the securitization of aid has become a major plank of US policy. The Trump administration plans significant cuts to the 2020 aid budget, focusing on reductions in funds for humanitarian aid, refugee assistance and global health programs (Morello, 2019). Harris et al (2017) are among a number of analysts who argue that the 'cuts are ... indicative of the wider push to tie development aid with U.S. national security interests' (Harris et al, 2017: 1). This orientation was illustrated in President Trump's first State of the Union speech, in which he stated that "I am asking Congress to pass legislation to help ensure American foreign assistance dollars always serve American interests and only go to friends of America, not enemies of America” (Trump, 2018).

At the supranational level, the World Bank is increasing its aid markedly to countries affected by conflict, violence and fragility. In March 2018, the International Development Association (IDA) section of the World Bank committed to increasing financing to fragile and conflict affected countries from $\$ 7$ billion to $\$ 14$ billion over the next three years (Igoe, 2018b). It will also train 150 staff to become specialists in issues relating to fragility, violence and conflict. The Bank emphasizes that the expansion is necessary because its success in ending extreme poverty globally 
'depends upon greater focus, stronger collaboration and deepening the effectiveness of our work in places where [fragility, violence and conflict] threatens so many lives (World Bank, 2018: i).

In sum, an increasing amount of aid from the World Bank is being directed to countries affected by conflict and some influential DAC donors are adopting a securitization agenda. These shifts are not without controversy. Easterly (2010) argues that aid to conflict affected countries has a track record of appropriation by undemocratic leaders and donors often do not address this issue. Aid to conflict affected countries has also been taken by opposition groups using violence in their efforts to control resources and territory, as well as political power. Furthermore, Moseley (2009) contends that increasing use of ODA for security purposes could lead to the 'blanket militarization' of aid.

However, Brown and Gravingholt, (2016) make the salient point that only some donor countries are explicitly shifting aid into an instrument of pursue their national or international economic, political and security interests. Recognising the importance of context specificity is, thus, necessary when analysing this issue. Research is required on which DAC donors are shifting towards giving aid primarily for securitization purposes, which are providing assistance guided, at least in part, by the main precepts of the Paris Declaration, and which have still other agendas, such as economic self-interest.

This section has shown that traditional aid has been subjected to increasing criticisms, and its bilateral providers driven in contradictory directions, despite their membership of a unitary body - the DAC. Contemporaneously, China has been growing in importance and influence as a supplier of foreign assistance, often blended with commercial investment in recipient countries. In the following section, notable elements of Chinese aid are outlined and the likelihood of cooperation or competition with DAC donors - in the light of their changing perspectives and modalities - is assessed.

\section{Chinese Foreign Assistance}

In 2018 the China International Development Cooperation Agency (CIDCA) was opened. The aims of the agency are to formulate 'strategic guidelines, plans and policies for foreign aid, coordinate and offer advice on major foreign aid issues, advance the country's reforms in matters involving foreign aid, and 
identify major programs and supervise and evaluate their implementation' (CIDCA, 2019). CIDCA's broader task is to make coordination more transparent and effective between the Ministry of Commerce (MOFCOM) and the Ministry of Foreign Affairs (MFA), which play key roles in directing the blending of Chinese ODA with commercial investments. A further noteworthy goal of CIDCA is to 'allow aid to fully play its important role in great power diplomacy’ (Reuters, 2018).

The creation of CIDCA is a considerable achievement for a country, which has raised 700 million people above the poverty line in the past thirty years (World Bank, 2016), accounting for almost $75 \%$ of global poverty reduction (United Nations Development Program, 2015). Brautigam (2010) makes the point that, while there are vociferous critics of its foreign assistance, China’s commendable record in alleviating poverty in recent history puts the country in a position to provide viable aid ideas, strategies and models.

Research on Chinese aid is increasing but significant gaps remain. A little more than a decade ago, China was labelled a 'rogue' donor and accused of 'pricing responsible and well-meaning aid organizations out of the market in the very places where they are needed most' (Naim, 2007). Since then a number of detailed overviews have shown this to be a simplistic perspective. Brautigam (2010) argues that Western analysts need to avoid sensationalism and paranoia about Chinese aid to Africa and may be better served by addressing the shortcomings of the DAC model. She outlines innovative ways in which China is blending aid and business activities in recipient countries. Brautigam also shows that China is trying to learn from the methods used effectively by aid donors in the past, and is willing to adjust its own strategies and practices, according to outcomes.

Recent research by Dreher et al (2017: 26) finds that Chinese aid 'boosts economic growth in recipient countries'. Moreover, 'Chinese, U.S. and OECD-DAC aid produce similar economic growth impacts. We also find no evidence to support the idea that Western aid is less effective at accelerating economic growth in countries that also have significant access to Chinese aid' (Dreher et al, 2017: 26). These findings have positive implications for a deeper aid relationship between China and DAC donors. However, for synergies between China and DAC donors to work effectively, greater depth of understanding is needed of how the former blends aid with other forms of investment. Xu and Carey (2015) are among researchers who argue that greater transparency concerning the way China provides assistance to 
foreign countries is needed. In addition, more micro-level empirical studies focusing on outcomes for aid recipients are required. Such research would be particularly useful in the context of Africa, given China's increasing levels of investment in, and assistance to, countries continent-wide.

Detailed studies of China's economic and political with Africa - both at a continent-wide and individual country-based level - are increasing. The China-Africa Research Initiative (CARI), based at Johns Hopkins University, has produced evidence-based analyses of various aspects of economic and political relationships since 2014. Oqubay and Yinfu Lin (2019) have edited a wide ranging examination of Africa's economic development in the context of its relationship with China. The research highlights the need for context specific assessments, given the diverse nature of political economy regimes across Africa. Alden and Large (2019) have coordinated an overview of methodological and theoretical approaches to studies of China-Africa relations, outlining areas where repositioning would be beneficial. This is timely, given that a number of analyses (Ndzendze, 2019, for example) point to the lack of robust theoretical analysis, which characterizes a number of China-Africa studies. Yuan Sun (2017) has examined the role of China in the ongoing industrialization process in Africa, outlining the possible economic, political and social changes that may ensue from the growing number of Chinese-run factories on the continent.

At a nation-state level, Oya (2018) has assessed labour regimes in Ethiopia and Angola, comparing conditions and relationships in Chinese-run workplaces with those financed by domestic and other foreign capitalists. Ching Kwan Lee (2018) has produced a detailed ethnographic assessment of varieties of Chinese capital investment in the copper mining and construction sectors in Zambia. Sylvanus (2013) has researched Chinese textile traders in Togo. She shows that there are shifting and dynamic relationships between Chinese and Togolese actors and institutions, with agency significant on both sides. Mohan and Lampert (2012) also demonstrate, using Nigeria as a case study, that African actors beyond the state level are increasingly negotiating and shaping engagements with China.

These studies provide nuanced analyses, highlighting the point that China is not simply dictating the pattern of its investment in Africa. In contrast, China's strategies and policies are dynamic and increasingly influenced by the agency of a variety of African actors, not just a state-elite. 
However, similarly detailed studies of Chinese aid to Africa are less in evidence. Yuan Sun, Jayaram and Kassiri (2017) make the point that more research is necessary on the outcomes of Chinese aid in particular contexts in Africa, rather than a focus on inputs and methods. This is not a simple task, since 'it is hard to identify data disaggregating China’s foreign aid'(Carter, 2017: 11). A few studies exist, focusing on particular sectors. King (2013), for example, has produced a study of Chinese aid to provide education and training in Africa. However, more micro-level research on Chinese aid programs and projects would act as a useful complement to the work of Dreher et al (2017) and Brautigam (2010), which takes a broader sweep in examining the effects of China's ODA to Africa.

Whether the increased production of evidence-based research showing the outcomes of Chinese aid would increase the possibilities of meaningful collaboration between China and traditional donors is debateable. A discussion between traditional DAC donors and China over aid provision is occurring. However, Yifu Lin and Wang (2017) point out that this dialogue needs to be wider, deeper and more transparent in order to generate effective collaboration. Both parties have misgivings concerning aspects of the others aid provision, which are not easily overcome. Yifu Lin outlines a New Structuralist Economy (NSE) model, which frames the way China provides assistance to other countries. This model is based on evidence that in the period following the end of the Second World War, developing economies which successfully achieved developed status, primarily used structuralist policies, based on state-led intervention (Yifu Lin and Wang, 2017). A prominent example is Japan, which provided aid to China based on this model of development. Influenced by these policies, and the form of ODA it received from Japan, China, therefore, situates its aid provision within an overarching vision of structural and state-centered change.

Within this broad perspective, however, the Chinese aid model is practically oriented and not propelled by an extensively researched and detailed 'conceptual model of development' (Xue, 2014: 41). Given the ideological adherence of the traditional donors to market-led aid and the increasingly critical stance of US aid agency officials towards the Chinese model, much work needs to be done if meaningful collaboration with China is to occur. 


\section{Conclusions}

ODA provided by traditional donors is at an inflexion point. Important changes are being driven by a number of complex and, in certain respects, contradictory influences. First, more than ten years after the publication of the Paris Declaration, which framed the way ODA should be provided by OECD-DAC donors, a considerable gap remains between the rhetoric and the reality of disbursement. The utility of the principles outlined in the Paris Declaration (and updated at Accra and Busan) is increasingly questioned. Second, a number of recent analyses of aid highlight ways in which traditional donors are failing to engage effectively with the deeply political nature of its provision. Third, traditional donors are increasingly giving primacy to private sector provision of ODA, influenced by neoliberal policy prescriptions for development. Fourth, ODA is facing concerted and trenchant criticism from a number of quarters, including neoliberal analysts, governments of major DAC providers, such as the US, and sections of the right-wing press in donor countries. These critiques emphasize the issues of poorly conceived programs, the venality and ingratitude of some recipients, as well as corruption and misbehavior on the part of officials at the aid agencies of donors. Fifth, largely due to the criticisms outlined above, there is a drift away from the two formative reasons for providing foreign assistance: the moral imperative and the belief that aid can improve the economic and social welfare of people in recipient countries. Instead, a number of traditional donors are overtly justifying the use of aid to pursue national interests, focusing on security concerns and their own economic gain.

Within this complex scenario, China's importance and influence as an aid provider continues to increase. Research shows that aid provided by China is having a beneficial impact on economic growth in recipient countries. Studies demonstrating positive economic outcomes from aid provided by DAC donors have also been produced. Thus, as Arndt, Jones and Tarp (2016: 472) argue, 'calls for the extinction of aid and its associated institutions on the basis of poor or negative returns are unjustified'.

These findings raise the question of how effective complementarity between aid provided by China and traditional donors can be increased. For this to happen more research is needed on the outcomes of particular Chinese aid programs and projects. This would add weight to the evidence showing a correlation in some countries between receiving Chinese aid and subsequent economic growth. More 
empirical research on how exactly China uses blending of foreign assistance with other types of investment would also be useful. The publication of detailed overviews of how blending works at program and project levels would help to dissipate the unease some DAC donors continue to exhibit about the nature of Chinese assistance. Such overviews could provide useful lessons for DAC donors, given their own shift towards blended aid provision. However, even with the publication of such research, the present ideologically-driven predilection of traditional donors for assistance led by the private sector, as well as moves on the part of some countries towards the provision of aid based on a securitization agenda, are factors complicating the possibilities of cooperation with China. Furthermore, research summarized in this chapter shows that traditional donors continue to provide much aid through misguided attempts to inculcate political reform in recipient countries. The research demonstrates that such efforts have little chance of success when they are set within the structural and financial constraints of the established aid system and the prioritization of a value for money (VFM) agenda on the part of donors. These restrictions render the policy coherence for development (PCD) agenda on the part of DAC donors largely meaningless. They also reduce the possibilities of effective complementarity between traditional and Chinese aid providers.

Nevertheless, the importance attached by the IFIs and DAC donors to achieving the Sustainable Development Goals by 2030 is an incentive for them to adjust their ideologies, strategies and practices. The SDGs are unlikely to be attained without considerable aid from China, as well as other non-traditional donors. This factor could incentivize the traditional aid donors to work more closely with China in providing aid. Given that this is an instrumental motivation, rather than one stemming from a wholehearted desire for cooperation and compromise, Chinese aid providers are likely to be cautious in the way they reciprocate.

Empirically, this chapter has focused mainly on Africa, where the proportion of people living in poverty has decreased in the last twenty years. However, the absolute number of poor people living on the continent increased in the same period due to rapid population growth in the poorest segments of society. Furthermore, quality jobs are scarce and young people, in particular, suffer from underemployment and a scarcity of secure wage-paying jobs (AU/OECD, 2018). Beyond the SDGs, therefore, an increase in the effectiveness of aid cooperation between China and the traditional Western donors in Africa would be useful in addressing these issues. 


\footnotetext{
${ }^{1}$ Major traditional multilateral aid donors, in the context of this chapter, are the World Bank, the International Monetary Fund and United Nations organisations. Traditional bilateral donors refer to the 29 OECD-DAC aid providers, as well as the European Union.

${ }^{2}$ Hereafter referred to as DAC donors.

${ }^{3}$ Arguments in favour of ODA are covered at a broad level only to frame the debates, as it is difficult to cover the 'vast array of different sub-literatures' (Riddell, 2008: xviii) on aid in detail in a single book chapter.

${ }^{4}$ A significant precursor to the four HLF was the International Conference on Financing for Development, held in 2002 in Monterrey. This produced the 'Monterrey Consensus' which outlines the need for aid to directly target poverty alleviation, based on developing effective partnerships between different agents of development. This was built on by the Doha Declaration on Financing for Development (2008) and the Addis Ababa Action Agenda (UNDESA, 2015), which align global 'financing flows and policies with economic, social and environmental priorities.' A progress report in 2017 found 'a difficult global environment has impeded individual and collective efforts, and many implementation gaps remain' (UNDESA, 2017).

${ }^{5}$ See, for example, DFID (2011) DFID's Approach to Value for Money https://www.gov.uk/government/uploads/system/uploads/attachment_data/file/67479/ DFID-approach-value-monev.pdf

${ }^{6}$ Statement by the Heads of the African Development Bank, the Asian Development Bank, the European Bank for Reconstruction and Development, the European Investment Bank, the Inter-American Development Bank, the World Bank Group and the International Monetary Fund (2015) From Billions to Trillions: Transforming Development Finance
}

\section{References}

Adams J. (2005) 'The Right Approach to the Right Policies: Reflections on Tanzania' in Gill I and T Pugatch (eds) At the Frontline of Development: Reflections from the World Bank

AFRODAD (2007) A Critical Assessment of Aid Management and Donor Harmonization Harare: AFRODAD

Alden C. and D. Large (eds) (2019) New Directions in Africa-China Studies

Abingdon: Routledge

Anders M. (2017) 'UK Cross-government Strategy in Crisis After Funds Suspended' in Devex Inside Development

Anders M. (2016) 'What More Private Investment Means for UK Aid?’ Devex Inside DevelopmentAvailable: https://www.devex.com/news/what-more-privateinvestment-means-for-uk-aid-89332 Accessed: 18 ${ }^{\text {nd }}$ April 2018

Anders M. and S. Edwards (2018) 'New DFID Leadership Team Sets Out Priorities' in Inside Development: The Future of DFID Available: 
https://www.devex.com/news/new-dfid-leadership-team-sets-out-priorities91997 Accessed: $15^{\text {th }}$ January 2019

Arndt, Jones and Tarp (2016) 'What Is the Aggregate Economic Rate of Return to

Foreign Aid?' in The World Bank Economic Review, Vol. 20, Issue 3

AUC/OECD (2018), Africa’s Development Dynamics 2018: Growth, Jobs and

Inequalities, AUC, Addis Ababa/OECD Publishing, Paris.

https://doi.org/10.1787/9789264302501-en Accessed 15 ${ }^{\text {th }}$ January 2019

Banks N, Hulme D. and M. Edwards (2015) 'NGOs, States and Donors Revisited: Still

Too Close For Comfort?' in World Development, Vol. 66

Barnett A. (2017) 'Boris Johnson Says Aid Money Will Be Used To Support British

Foreign Policy In 2018’ Independent News: The Daily Briefing

Available: https://inews.co.uk/news/boris-johnson-says-aid-money-will-used-support-

british-foreign-policy-2018/ Accessed: $18^{\text {th }}$ April 2018

Bauer P. (1976) Dissent on Development Cambridge MA: Harvard University Press

Bauer P. (1981) Equality, the Third World and Economic Delusion Cambridge MA:

Harvard University Press

Booth D. (2003) 'Introduction and Overview' in Development Policy Review, 21/2

Boughton J and A. Mourmouras (2002) 'Is Policy Ownership An Operational

Concept?’ IMF Working Paper WP/02/72, April 2002

Buiter W. (2010) ““Country Ownership”: A Term Whose Time Has Gone’ in

Cornwall A. and D. Eade (eds) Deconstructing Development Discourse:

Buzzwords and Fuzzwords Rugby: Practical Action Publishing and Oxfam, GB

Brown S and J. Gravingholt (eds) (2016) The Securitization of Foreign Aid

Basingstoke: Palgrave Macmillan

Carter B. (2017) A Literature Review on China's Aid Knowledge, Evidence and

Learning for Development (K4D) Helpdesk Report

Castel-Branco C. (2008) Aid Dependency and Development: A Question of

Ownership? A Critical View IESE Working Paper 01/2008

Chen W. (forthcoming) Chinese Private Investment, Focusing on SMEs in Ethiopia's

Light Manufacturing and Construction Material Industries

China International Development Cooperation Agency (CIDCA) (2019) What We Do http://en.cidca.gov.cn/2018-08/01/c_259525.htm Accessed: $7^{\text {th }}$ January, 2019

Ching Kwan Lee (2018) The Specter of Global China: Politics, Labor and Foreign

Investment in Africa Chicago: Chicago University Press 
Cramer C. (2002) Own Up! Does Anyone Out There Have a Decent Theory of Ownership? London: School of Oriental and African Studies

Danish J. (2016) ‘Afghanistan’s Corruption Epidemic is Wasting Billions in Aid’ in The Guardian. Available: https://www.theguardian.com/global-developmentprofessionals-network/2016/nov/03/afghanistans-corruption-epidemic-iswasting-billions-in-aidAccessed: $18^{\text {th }}$ April 2018

Department For International Development (2017) Economic Development Strategy: Prosperity, Poverty and Meeting Global Challenges London: DFID

Dijkstra G. (2017) ‘Aid and Good Governance: Examining Aggregated Unintended Effects of Aid in Evaluation Planning, September 2017

Dornan M. (2017) 'How New is the 'New' Conditionality? Recipient Perspectives on Aid, Country Ownership and Policy Reform’ in Development Policy Review, Vol 35/S1, July 2017

Dreher et al (2017) Aid, China, and Growth: Evidence from a New Development Finance Dataset AidData Working Paper 46, College of William and Mary Easterly W. (2010) 'Foreign Aid for Scoundrels' in New York Review of Books, November $25^{\text {th }}$, 2010

Easterly W. (2016) The Economics of International Development: Foreign Aid Versus Freedom For The World's Poor London: IEA

Edwards S. (2014) 'Economic Development and the Effectiveness of Foreign Aid: A Historical Perspective’ NBER Working Paper 20685, November 2014 Fisher M. and H. Marquette (2016) “Empowered Patient” or “Doctor Knows Best”? Political Economy Analysis and Ownership in Development in Practice, 26:1 Flint A and C Meyer zu Natrup (2014) 'Ownership and Participation: Towards a Development Paradigm Based on Beneficiary-led Aid’ in Journal of Developing Societies, Vol. 30, No. 3

Foulkes I (2018) ‘Oxfam Scandal: UN Agencies Fear Backlash’ BBC News Online Available: http://www.bbc.co.uk/news/world-europe-43066986 Accessed: $1^{\text {st }}$ April 2018

Friedman M. (1995) Foreign Economic Aid: Means and Obectives Stanford Calif. : Hoover Institution on War, Revolution and Peace 
Gauoette N. (2018) ‘Trump Admin wants to Slash Funding for Diplomacy’ CNN Politics. Available: https://edition.cnn.com/2018/02/12/politics/trump-budgetstate-department-aid-cut/index.html Accessed: 29 ${ }^{\text {th }}$ March 2018

Glennie J. (2014) ‘Aid Effectiveness’ in Desai V. and R. Potter (eds) The Companion to Development Studies (Third Edition) Abingdon: Routledge

Grindle M. (2007) 'Good Enough Governance Revisited' in Development Policy Review, Vol. 25, Issue 5

Harris B et al (2017) 'The End of Foreign Aid as we know it' in Foreign Policy, April $24^{\text {th }}, 2017$

Hayter T (1971) Aid as Imperialism London: Penguin

Heinrich T, Kobayashi Y, \& K. Bryant (2016) 'Public Opinion and Foreign Aid Cuts in Economic Crises' in World Development, Vol 77

Helleiner G. et al (1995) Report of the Group of Independent Advisers on Development Issues Between Tanzania and its Aid Donors Copenhagen: Royal Danish Ministry of Foreign Affairs.

Hirsch A (2018) ‘Oxfam Abuse Scandal is Based on the Aid Industry’s White Saviour Mentality' in The Guardian, February 20 ${ }^{\text {th }}, 2018$

Hulme D. (2016) Should Rich Nations Help The Poor? Cambridge: Polity

Igoe M. (2018a) USAID Adopts Hardline on China's Development Approach

Devex: Inside Development

Igoe M (2018b) The World Bank’s Pivot to Fragile States Devex: Inside Development

Independent Commission for Aid Impact (2018) The Conflict, Stability and Security Fund's Aid Spending: A Performance Review London: Independent Commission for Aid Impact

Jackson P. (2012) Value for Money and International Development: Deconstructing Myths to Promote a More Constructive Discussion Paris: OECD

Johnson J. and S. Wasty (1993) 'Borrower Ownership of Adjustment Programs and the Political Economy of Reform’ World Bank Discussion Paper, No. 199 Washington DC: World Bank

Jayasuriya D. (2013) 'What is Value for Money in Aid Programs’ DevPolicyBlog Available: http://www.devpolicy.org/what-is-value-for-money-in-aid-programs20130819-1/Accessed: 30 ${ }^{\text {th }}$ March 2018 
Katek M (2015) Policy Coherence for Development: Still Some Way To Go European Parliament Briefing, May 2015

Kentikelenis, Stubbs and King (2016) 'IMF Conditionality and Development Policy Space, 1985-2014' in Review of International Political Economy, 2016

Kenny C. (2017) Results not Receipts: Counting the Right Things in Aid and Corruption Washington DC: Center for Global Development

Killick T. (1997) 'Principals, Agents and the Failings of Conditionality’ in Journal of International Development, Vol. 9, No.4

King K. (2013) China's Aid and Soft Power in Africa: The Case of Education and Training Woodbridge: James Currey

Lawrence P (2018) Whither Large International Non-Governmental Organisations?

Which Functional and Structural Choices do International Development Charities Need to Consider to Enable them to Thrive in a Fast Changing, Challenging Context, While Remaining True to their Values? Third Sector Research Centre: Plowden Fellowship Report

Latek M. (2015) Policy Coherence for Development: Still Some Way To Go Luxembourg: Publications Office of the European Union

Leal P. (2010) 'Participation: The Ascendancy of a Buzzword in the Neoliberal Era' in Cornwall A. and D. Eade (eds) Deconstructing Development Discourse: Buzzwords and Fuzzwords Rugby: Practical Action Publishing and Oxfam, GB Leiderer, S. (2015) 'Donor Coordination for Effective Government Policies?' in Journal of International Development, Vol. 27, Issue 8

Manning R (2012) Aid as a Second-Best Solution: Seven Problems of Effectiveness and How to Tackle Them Helsinki: UNU-Wider, Working Paper No. 2012/24 Mawdsley E, Savage L and S. Kim (2014) 'A 'Post-Aid World'? Paradigm Shift in Foreign Aid and Development Cooperation at the 2011 Busan High Level Forum' in The Geographical Journal, Vol. 180, Issue 1

McGillivray M. et al. (2011) 'Does Aid Work for the Poor’? University of Otago Economics Discussion Paper No. 1114, December 2011

McQuinn M. (2012) Civil Society as Conflictual Sphere in Post-liberalization Tanzania: The Roles of NGOs and Trade Unions Saarbrucken: LAP Lambert Mohan G. and B. Lampert (2013) 'Reinserting African Agency Into China-Africa Relations’ in African Affairs, Volume 112, Issue 446 
Moise J (2018) ‘What Oxfam’s Ugly Scandal Reveals about Aid and Power in Haiti’ in The Washington Post, February 23 ${ }^{\text {rd }}, 2018$

Morello C. (2019) 'Budget Calls for Deep Cuts to Foreing Aid, Especially for Refugees and in Humanitarian Crises' in Washington Post, March 11, 2019

Moseley W. (2009) 'Stop the Blanket Militarization of Foreign Aid’ in Foreign Policy, July 31 ${ }^{\text {st }}, 2009$

Moyo D. (2010) Dead Aid: Why Aid is Not Working and How There is Another Way for Africa London: Allen Lane

Naim M (2007) 'Rogue Aid’ in Foreign Policy, 159 (March/April 2007)

Ndzenze B. (2019) 'On the Lack of Theory in Africa-China Analysis' in Journal of International Affairs, Jan $24^{\text {th }} 2019$ Columbia SIPA

Oqubay A. and J. Yinfu Lin (eds) (2019) China-Africa and an Economic

Transformation Oxford: OUP

Organisation for Economic Cooperation and Development (2009) Better Aid: Managing Aid - Practices of DAC Member Countries Paris: OECD

Organisation for Economic Cooperation and Development (2011) Busan High Level Forum on Aid Effectiveness Paris: OECD

Organisation for Economic Cooperation and Development (2015) Policy Coherence for Inclusive and Sustainable Development Paris: OECD and Post-2015 Reflections, Element 8, Paper 1

Organisation for Economic Cooperation and Development (2008) The Accra Agenda for Action Paris: OECD

Organisation for Economic Cooperation and Development (2003) The First High Level Forum on Aid Effectiveness, Rome

Organisation for Economic Cooperation and Development (2005) The Paris Declaration on Aid Effectiveness Paris: OECD

Olivie I (2016) ‘Why Don’t Donor Countries Coordinate their Aid? A Case Study of European Donors in Morocco’ in Progress in Development Studies, 16/1 Overseas Development Institute (2018) China’s New Development Agency: Five Expert Views London: Overseas Development Institute, March 14 ${ }^{\text {th }}, 2018$ Oxfam (2012) Busan in a Nutshell: What next for the Partnership for Effective Development Cooperation? Oxfam Briefing Note, 2 October 2012

Oya C. (2018) Labour Regimes and Workplace Encounters Between China and Africa IDCEA Working Paper 05, November 2018 
Oya, C. and N. Pons-Vignon (2010) ‘Aid, Development and the State in Africa' in V. Padayachee (ed) The Political Economy of Africa London: Routledge

Paul, E. (2015) 'Performance-Based Aid: Why It Will Probably Not Meet Its Promises' in Development Policy Review, Vol. 33, Issue 3

Pickard M. (2010) Reflections on Relationships: The Nature of Partnership According to Five NGOs in Southern Mexico in Cornwall A. and D. Eade (eds)

Deconstructing Development Discourse: Buzzwords and Fuzzwords Rugby: Practical Action Publishing and Oxfam, GB

Pingjian Z (2018) ‘As FOCAC Beijing Summit Draws Near’ in Forum on ChinaAfrica Cooperation March 16 ${ }^{\text {th }}, 2018$

Ramalingham B. (2013) Aid on the Edge of Chaos: Rethinking International Cooperation In A Complex World Oxford: Oxford University Press

Reuters (2018) China Says New Aid Agency Will Improve Coordination Reuters Business News, March $13^{\text {th }} 2018$

Riddell R. (2008) Does Foreign Aid Really Work? Oxford: Oxford University Press

Riddell R. (2011) The Moral Case for Aid Thousand Oaks CA: Sage

Rose S. and F. Wiebe (2015) Focus On Country Ownership: MCC's Model In Practice Washington DC: Center for Global Development, MCC Monitor

Sachs J (2014) 'The Case for Aid’ in Foreign Policy, January 21 ${ }^{\text {st }}, 2014$

Sachs J. (2015) The End of Poverty: Economic Possibilities for our Time New York: Penguin, Random House

Sachs J (2017) 'The Ethics and Practicalities of Foreign Aid’ in The Boston Globe, March $13^{\text {th }}, 2017$

Singer (1972) 'Famine, Affluence, and Morality’ in Philosophy and Public Affairs, Vol 1, No 1 Spring 1972

Smith B. (2007) Good Governance and Development Basingstoke: Palgrave Macmillan

Swedlund H. (2017) The Development Dance: How Donors and Recipients Negotiate the Delivery of Foreign Aid Ithaca and London: Cornell University Press

Sylvanus N (2013) Chinese Devils, the Global Market, and the Declining Power of Togo’s Nana-Benzes in African Studies Review, Vol. 56, Issue 01

Trump D. (2018) State of the Union Speech, 30 $0^{\text {st }}$ January 2018 Available: https://www.youtube.com/watch?v=jznoIlUyPmc_Accessed: April 18th 2018 
United Nations Department of Economic and Social Affairs (2015) Addis Ababa Action Agenda of the Third International Conference on Financing for Development New York: United Nations

United Nations Department of Economic and Social Affairs (2008) Doha Declaration on Financing for Development New York: United Nations

United Nations Department of Economic and Social Affairs (2017) Financing for Development: Progress and Prospects - Report of the Inter-agency Task Force on Financing for Development 2017 New York: United Nations

United Nations Development Program (2015) Discussion Paper: China, The Millennium Development Goals and the Post-2015 Development Agenda Beijing: UNDP-China

Vogus A. and K. Graff (2015) PEPFAR Transitions to Country Ownership: Review of Past Donor Transitions and Application of Lessons Learned to the Eastern Caribbean Global Health: Science and Practice

Watson-Grant S. et al (2016) Country Ownership In International Development: Towards a Working Definition Chapel Hill, NC: MEASURE Evaluation and USAID

Weeks J. et al (2002) Supporting Ownership: Swedish Development Cooperation with Kenya, Tanzania, and Uganda Stockholm: SIDA Evaluation 02/33

Whaites A. et al (2015) A Governance Practitioners Notebook: Alternative Ideas and Approaches Paris: OECD

Whitfield L (2009) 'Reframing the Aid Debate: Why Aid Isn’t Working and How It Should Be Changed’ DIIS Working Paper 2009:34

Winters M. (2012) 'The Obstacles to Foreign Aid Harmonization: Lessons from the Decentralization Sector in Indonesia' in Studies in Comparative International Development, Vol 47, Issue 3

Woods N (2008) 'Whose Aid? Whose Influence? China, Emerging Donors and the Silent Revolution in Development Assistance' in International Affairs, 84/6

World Bank (2004) Guidelines for Joint Staff Assessment of Poverty Reduction Strategy Papers Washington, DC: World Bank

World Bank Group (2015) Joint Statement from MDBs and IMF Head on Financing for Development 
From Billions to Trillions - Transforming Development Finance: Post-2015

Financing for Development: Multilateral Development Finance Washington DC: World Bank Group, April 16 ${ }^{\text {th }}, 2015$

World Bank (2018) Maximizing the Impact of the World Bank Group in Fragile and Conflict-Affected Situations Washington DC: World Bank

World Bank (1988) Progress in Implementation of Adjustment Lending: An Evaluation of Ten Years Experience Washington DC: World Bank

World Bank (2016) Understanding China's Poverty Reduction Success To Benefit The Global South. Available:

http://www.worldbank.org/en/news/feature/2016/05/17/understanding-chinas-

poverty-reduction-success-to-benefit-the-global-south Accessed: $18^{\text {th }}$ April 2018

Xu J. and R. Carey (2015) China's International Development Finance: Past, Present and Future WIDER Working Paper 2015/130. Helsinki: UNU-WIDER.

Xue L. (2014) China's Foreign Aid Policy and Architecture IDS Bulletin, Vol. 45, No, 4

Yanguas P. (2018) Why We Lie About Aid: Development and the Messy Politics of Change London: Zed Press

Yifu Lin, J. and Y. Wang (2017) Going Beyond Aid: Development Cooperation for Structural Transformation Cambridge: Cambridge University Press

Yuan Sun I. (2017) The Next Factory of the World: How Chinese Investment Is Reshaping Africa Boston: Harvard Business Review Press Yuan Sun I, Jayaram K. and O. Kassiri (2017) Dance of the Lions and Dragons : How are Africa and China Engaging, and How will the Partnership Evolve? McKinsey Global Institute 